\title{
FIRE SAFETY PRECAUTIONS TAKEN AS A RESULT OF FIRE ENVIRONMENT ANALYSIS IN INTENSIVE CARE UNITS AND PATHOLOGY LABORATORIES ${ }^{1}$
}

\section{YOĞUN BAKIM VE PATOLOJI LABORATUVARLARINDAKİ YAN- GIN ORTAMININ İNCELENMESI SONUCU YANGIN GÜVENLIKK ÖNLEMLERININN OLUŞTURULMASI}

\author{
Zuhal ŞIMSSEK', Recep YAMANKARADENIZZ2, Nilüfer AKINCITÜRK ${ }^{3}$, \\ Nurettin YAMANKARADENIZ ${ }^{4}$, Hande UFAT ${ }^{5}$ \\ ${ }^{1}$ Uludă̆ University Faculty of Architecture, Architecture Department, Bursa / Turkey \\ ${ }^{2}$ Uludă University Mechanical Engineering Depatment, Bursa / Turkey \\ ${ }^{3}$ Uludă University Faculty of Architecture, Architecture Department, Bursa / Turkey \\ ${ }^{4}$ Uludăg University Vocational School of Technical Sciences, Bursa / Turkey \\ ${ }^{5}$ Uludăg University Mechanical Engineering Depatment, Bursa / Turkey
}

Öz: Hastanelerde laboratuvarlarında patlayıcı ve düşük parlama ve tutuşma sıcaklığına sahip kimyasalların bulunması yangın riskini arttırmaktadır. Yoğun bakım üniteleri ise, tahliye stratejisi bakımından en riskli alanlar içerisindedir .Çalışmada, yangın riski oluşturan bu mekanlarda yangın anında oluşan ortam koşullarının CFD yazılımları arasında yer alan PHOENICS programı ile bir örnek yapı üzerinden incelenmesi sonucu, dumanın ilerlemesinin engellenmesi ve zehirli gazların en kısa zamanda ortamda uzaklaştırılarak, güvenli ortamın sağlanması amaçlanmıştır. Ayrıca, mekanların yapı içindeki konumlarının belirlenerek, pasif önlemlerin oluşturulması da çalışmanın bir diğer amacını oluşturmaktadır. Laboratuvardaki dumanın hareketi, yoğunluğu, ortamın sıcaklığı, görüş mesafesi ve zehirlilik yüzdelerinin ölçülmesi amacı ile bir yangın senaryosu oluşturulmuş ve sonuçlar değerlendirilmiştir.

Anahtar Kelimeler: Yangın Güvenliği, Patoloji Laboratuvarı, Yoğun Bakım Üniteleri
Abstract: Explosives and chemicals with low combustion points, which are found in pathology laboratories in hospitals increase the fire risk. Intensive care units are one of the most risky areas in terms of user movement and evacuation strategy. This study, aimed to provide a safe environment by preventing smoke diffusion within the shortest possible time in the most economical way, by determining the fire risk of a building as a result of the analysis of environmental conditions created during a fire. It was also aimed to establish passive precautions by determining locations high fire risk places. A fire scenario was created to compare the efficiency of the recommended system with the measurements of the movement, intensity, environment temperature, visibility distance and toxicity percentage of the smoke in the laboratory and the results were evaluated by modelling with the Phonics Flair program

Key Words: Fire Safety, Pathology Laboratory, Intensive Care Unit

Doi: $10.17365 / T M D .2016716511$

(1) Corresponding Author: Zuhal ŞİMŞEK, Uludă University Faculty of Architecture, Architecture Department, Bursa / Turkiye zumanav2002@hotmail.com Received: 27.12.2015 Accepted: 13.03.2016 Type ofarticle (Research -Application) Conflict of Interest:Yok/None "None of Ethics Committee" 


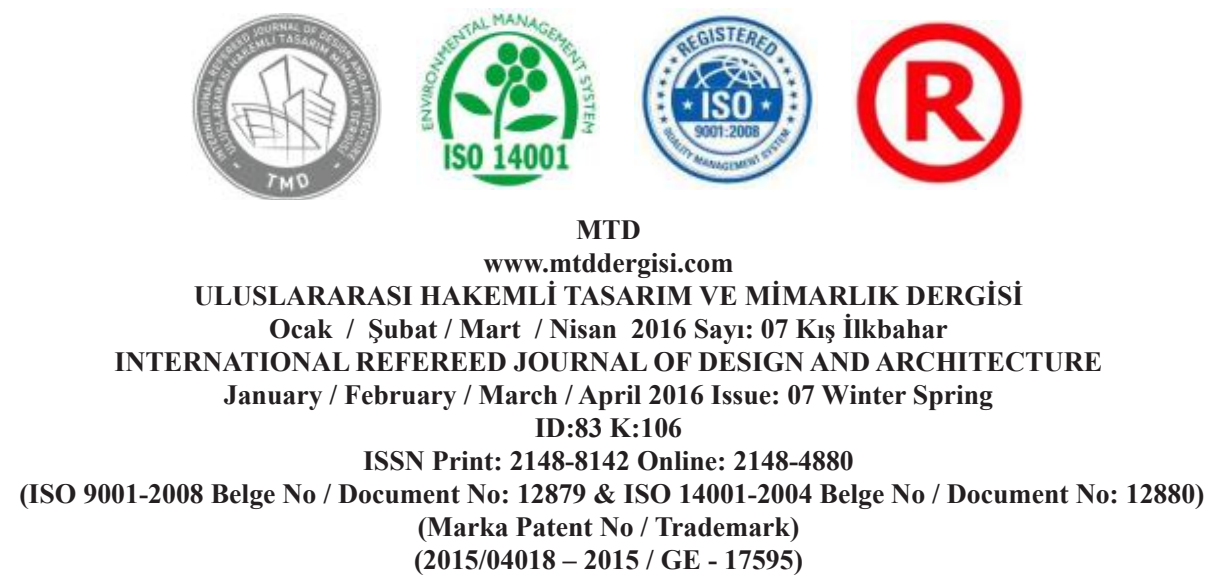

\section{INTRODUCTION}

In hospitals, the ability for comment of patients may be limited, therefore special fire safety precautions should be taken. When data obtained from the NFPA is analyzed, it is seen that deaths result from smoke poisoning (Proulx, 2002). According to the Fire Protection Regulation 2009 provision 49-1, it is very important to create compartments that do not allow smoke leakage [5]. However, when fire breaks out in inpatient units or smoke leaks into these areas, patients are exposed to smoke for a certain time. In the regulations, there is no implementation regarding the evacuation of smoke from these spaces. Changing the location of patients on life-support endangers their lives considerably. In 2009, a fire broke out in Bursa Şevket Yılmaz State Hospital, smoke reached the intensive care units and 9 people lost their lives. According to the report published after the fire, $\mathrm{CO}$ was not found in the blood of any patient (Anonymous b, 2009). This shows that the evacuation of smoke is essential before changing the location of patients treated in intensive care units until the fire is taken under control. In this context, fire risk can be divided into two groups. The first is the risk caused by the movement ability of the user and the second is the risk caused by the inflammable nature of the materials found in the area. When flammable and explosive materials are found in areas connected with patient units where the patients have low mobility, physical and financial losses increase dramatically. The fire risk in hospitals will be minimized by reducing the risks caused by the environmental conditions exposed because of the limited mobility of patients, and flammable and explosive materials as a source of fuel and ignition (Shields and Silcock, 1987).

Pathology laboratories are among the units at highest risk of fire as many flammable and explosive chemicals are found there and there is a relationship with units of dormant risk (http://laboratuvar.com). The chemicals used in the analysis of the biological materials of patient and autopsy samples present many dangers (Jegathesan ve ark 1988:1-5). In this regard, 17 hospitals in Bursa were analyzed and it was determined that no fire compartment or smoke evacuation systems were used in these hospitals, 2013). No article meets the regulation provisions as specified as below, which includes the current safety status of intensive care units and pathology laboratories in the sample hospital.

- Escape routes and staircases are not eligible

- There isn't any horizontal evacuation compartment area

- Smoke resistant isn't provided in shafts 

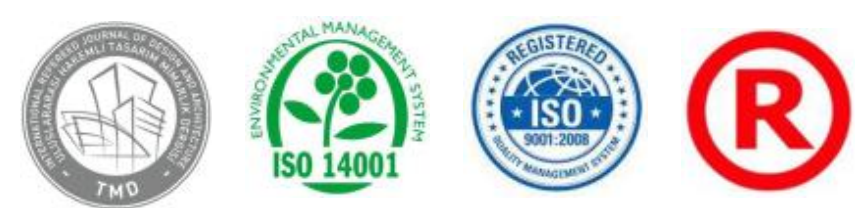

MTD

www.mtddergisi.com

ULUSLARARASI HAKEMLİ TASARIM VE MIMMARLIK DERGİSI

Ocak / Şubat / Mart / Nisan 2016 Sayı: 07 Kış İlkbahar

INTERNATIONAL REFEREED JOURNAL OF DESIGN AND ARCHITECTURE

January / February / March / April 2016 Issue: 07 Winter Spring ID:83 K:106

ISSN Print: 2148-8142 Online: 2148-4880

(ISO 9001-2008 Belge No / Document No: 12879 \& ISO 14001-2004 Belge No / Document No: 12880)

(Marka Patent No / Trademark)

$(2015 / 04018-2015 /$ GE - 17595)

- Fire ladders aren't accordance with provisions

- There isn't any emergency lifts

- Electrical systems aren't accordance with provisions

- Alarm \& detectors aren't accordance with provisions

- There isn't any smoke control system

- There isn’t any fire extinguishing system

- Explosive and flammable gas are available in laboratory

- There isn't any measures taken about LPG

- Interior finishes haven't fire resistance performance

- Hallway doors haven't got smoke resistant capability

- All places are relations with dangerous places

- There isn't smoke damper in ceiling panels and vertical shaft

- Compartment opens to the vertical shaft

- Chemical gas or materials accelerate burning in laboratory

Only Staff training, applied evacuation drills meets the regulation provision.
In this situation, it is seen that patients with limited or no mobility are at risk of smoke poisoning in the event of a fire breaking out in a hospital pathology laboratory [24]. Thus, the evacuation of smoke from the environment is very important and can be applied through natural or mechanical methods. However, the cost of implementing active and passive fire safety precautions in current building is extremely high. Natural smoke evacuation is not always sufficient so smoke evacuation applied mechanically will be required to create a sufficiently safe environment. A drawback to this is that the demolition and rebuilding work to add ventilator and smoke shafts to the building may disrupt hospital activities causing delays in healthcare services and creating hygiene and noise problems. In addition, when funds allocated to state institutions are not sufficient, these kind of improvements have to be made in the most economical way. To eliminate the risks in the pathology laboratories of existing hospitals it is becoming increasingly important to carry out these improvements without demolition if possible and by completing renovations in the shortest possible time.

\section{MATERIAL and METHOD}

Smoke evacuation systems were created with CFD solutions using the Phonics program, by analysis of the smoke movement in fires in intensive care units and in the pathology 


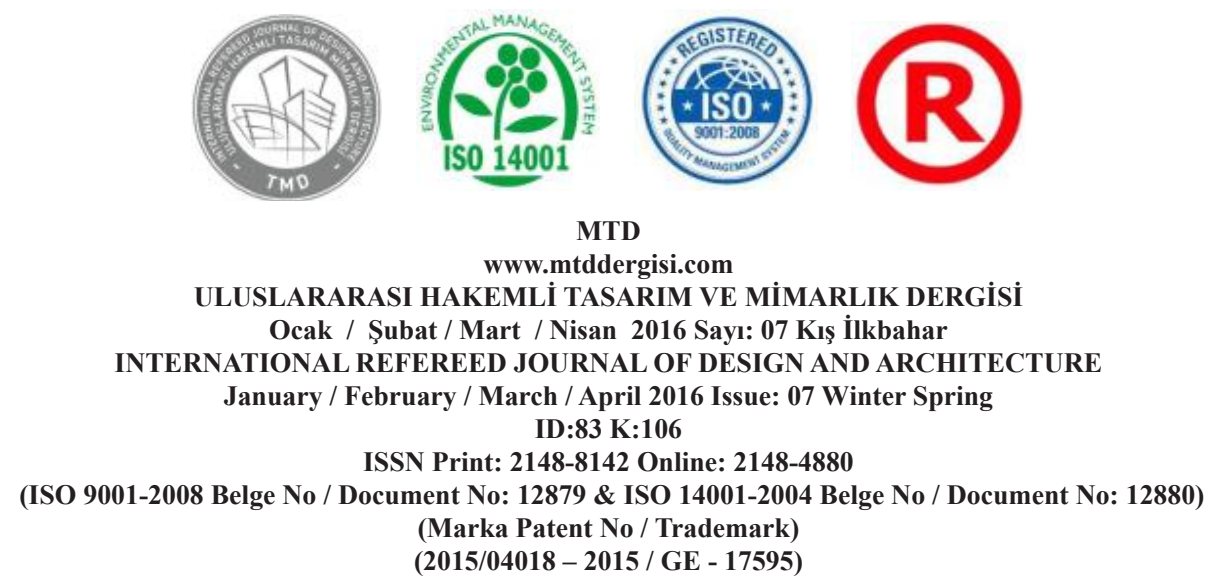

laboratory. Safety criteria and smoke movement of the environment and numerical safety limits of created with a fire scenario modelled. The "Field" model domain created with CFD analyses is divided into small cells to analyze the temperature, heat and smoke flow values (Vistnes, 2004). The smaller the range of these cells (mesh), then the more accurate data can be obtained. Solutions regarding the extinguishing phase were discussed only on the basis of fire regulation provisions and were not included in the CFD solutions as they are not an area of expertise in architecture.

\subsection{Creating the Scenario}

Pathology laboratory and intensive care unit of "Uludağ University Application and Research Hospital", which provides one of the most comprehensive hospital services in Turkey, was chosen as the sample building. In both scenarios, it was hypothesized that the fire broke out as a result of electrical failure in the pathology center corridors, where materials had been left in front of electricity shafts and in areas of the sample where wooden shaft covers were located in the installation channels. The old hospital buildings with complicated electricity networks cause overloading of the electrical system. When electrical installations have not been replaced with fiber optic cables that do not emit poisonous smoke and transmit flames, the fire risk increases and small scale fires break out in the building. Therefore, fire can also break out in a pathology laboratory (Harrıngton and Shanno, 1977:626-628]. It is also assumed that leaving stretchers and storage materials in front of wooden shaft covers enables flames and smoke to spread quickly through the building. It would be very costly and difficult to set up smoke evacuation systems and smoke shafts in existing buildings. Therefore, with the condition that windows which open on to airshafts are fire-resistant, the air-conditioning cavities in intensive care and laboratory departments can each be evaluated as a smoke shaft. Directing smoke to the shaft through the shaft enables a smoke exhaust to be made without creating a new vertical shaft or removing floor and wall coverings. Modelling was made of the storage, archive, histology chemistry laboratory, routine tissue tracking laboratory, sample acceptance unit, cytology, microscopy and macroscopy units found in the pathology laboratory (scenario a). The offices of the microbiology department academic staff were separated visually and functionally from the laboratory with glass PVC doors. In addition to the aforementioned areas in the laboratory, 1 air shaft of $540 / 360 \mathrm{~cm}$ in dimension was included in the three dimensional modelling.

In the intensive care units (scenario b), the reanimation unit and support units were mod- 


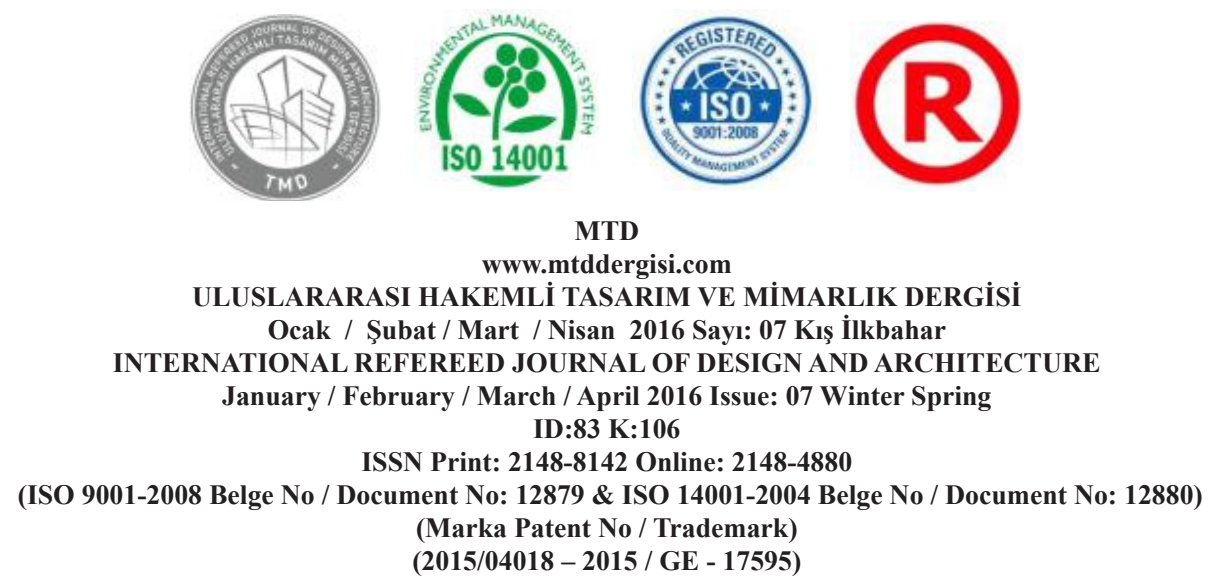

elled. An extractor fan which would remove smoke was put into place providing the same conditions of an air-conditioning shaft as in the inpatient units. When the fans were operated, the concentration in these areas and that the velocity vectors were correctly directed into the shaft confirmed the correctness of the solution. When it is necessary to increase pressure in these areas, negative results may be engendered, such as not being able to open fire doors. To prevent this situation, the air supply should be adjusted to remain lower than $100 \%$. In this context, air outlets and exhaust fans should be designed in the right place and with correct direction of air movement to make smoke evacuation possible. Air shafts in existing buildings are used in this way to provide minimum disturbance to patients from renovation work, reducing both repairs within the building and modification costs. It is recommended that a shaft be created that is resistant to fire for 120 minutes by closing all spaces on this shaft or changing the windows to be fire-resistant for 120 minutes.
In both scenarios (A and B), before setting up any smoke evacuation system in the existing building conditions, an analysis was made of smoke density, visibility distance and the route which smoke will follow horizontally in case of fire. In the second stage, the change between parameters specified in case of setting up smoke evacuation systems and the effects of emerging environment conditions on human safety were observed. In the pathology laboratory as a $3^{\text {rd }}$ alternative, the alcoholic compound on a stretcher found in front of the shaft covers was defined and evaluated. The value of the stoichiometric ratio, which is defined as the air/fuel ratio, is changed when there is alcohol in a fire. When all the bonds of components such as carbon and hydrogen found together in a substance, combine with oxygen, this reaction is called stoichiometric combustion. If there is a high level of oxygen, combustion is weak and when oxygen levels are lower, combustion is stronger. A value of 14.6 has been calculated for stoichiometric combustion in alcohol fires. Evaluations were made using separate codes given for each scenario. The explanations of the codes are below:

\begin{tabular}{ll} 
Scenario A : & Current situation of the pathology laboratory \\
\hline Scenario A1: & Pathology Laboratory-wood furniture fire with smoke evacuation sys. \\
\hline Scenario A2 : & Pathology Lab.alcohol placement of fire with smoke evacuation sys. \\
\hline Scenario B : & Current situation of the intensive care unit \\
\hline Scenario B1 & Intensive Care unit-wood furniture fire with smoke evacuation system \\
\hline
\end{tabular}




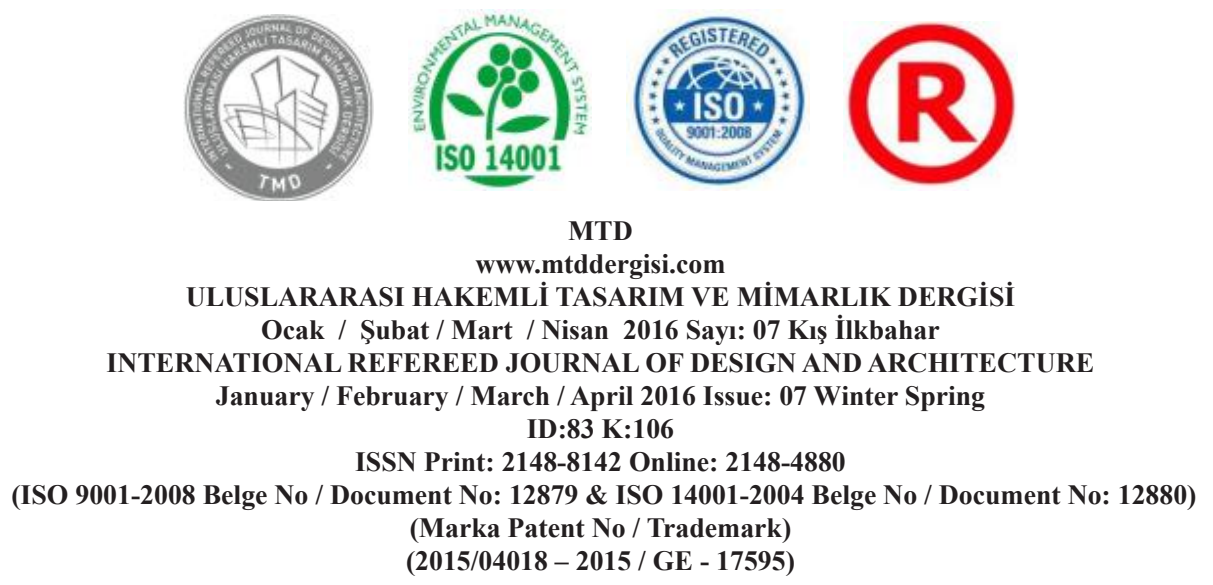

\subsection{Creating General Data for the Program}

It was assumed that all the doors of the laboratory were open to the corridors and there was oxygen feeding the fire in the place where it started. The heat and speed of the fires were determined as $2.510^{7} \mathrm{~kg} / \mathrm{j}$ value according to NFPA 99A. As flammable materials were limited, the flame height of the designed fire was accepted as $2 \mathrm{~m}$ and the mean environment temperature in both cases was taken as $20^{\circ} \mathrm{C}$ (Anonymous a,2009). (Shields ve Silcock, 1987). The dimensions

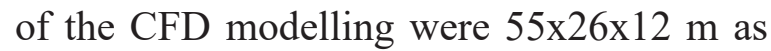
the dimensions of the clinic and in the simulation, $217 \times 96 \times 78$ cells were used. All walls, columns, ceilings and floors were accepted as adiabatic. Temporary behaviors such as temperature, density and speed in the spread of smoke were simulated with the k-e turbulence model (K Model). Hyper differential correction was used to evaluate areas of temperature and speed on the domain. In fire modelling, the solution is time-dependent and when there is heat release, the fire source acts like a big electric heater. In addition, with the combustion of wooden shaft covers in the environment, the fire is defined as growing from moderate speed to high speed (NFPA 92 B). In NFPA 99B, a rapidly developing fire is defined as one which can reach its maximum combustion rate at the end of 300 seconds. A fast developing fire was designed. According to the fast fire table in NFPA99, that changes are time-dependent and taking the conditions of $a=46,90000$ and $b=20$, the "released maximum temperature value" was calculated using the formula: Heat $=\min (\mathrm{Qmax}, \mathrm{ax}(\mathrm{t}-$ $\left.\mathrm{t}_{0}\right)^{\wedge} \mathrm{b}, \mathrm{Q} \max =1055000$ Wat.

\section{Correlations and other values used in fire model are below:}

Heat of Combustion Hfu $=2.500010^{7} \mathrm{~J} / \mathrm{kg}$-fuel, Radiative heat fraction $\mathbf{R} \mathbf{f}=0.333$ (CIBSE Guide E), Particulate smoke yield Ys in kg-particulate-smoke $=0.02 / \mathrm{kg}$-fuel (CIBSE Guide E), "Stoichometric ratio Rox"= $1.000000 \mathrm{~kg}$-oxygen $/ \mathrm{kg}$-fuel, Mass specific extinction coefficient $\mathbf{K m}=7600.000 \mathrm{~m}^{2} / \mathrm{kg}$ particulate-smoke, Smoke conversion factor $=10 \% \mathrm{Dm}=300 \mathrm{~m}^{2} / \mathrm{kgsoot}$ ).

The positions of fans were changed in order to measure the most effective system in the dispersion of smoke, their power was increased and changes between them were observed. Especially in the CFD analyses, there was a definite need for a propellant force to expel the smoke from the prescribed exhaust fans in all the samples applied. It was seen that the exhaust fans alone could not extract the smoke. Therefore, to be able to create a counter force, fans providing clean air ingress and facing both corridors were put on one of the shafts. When the clean air needed to clean the smoke and create airflow was positioned 


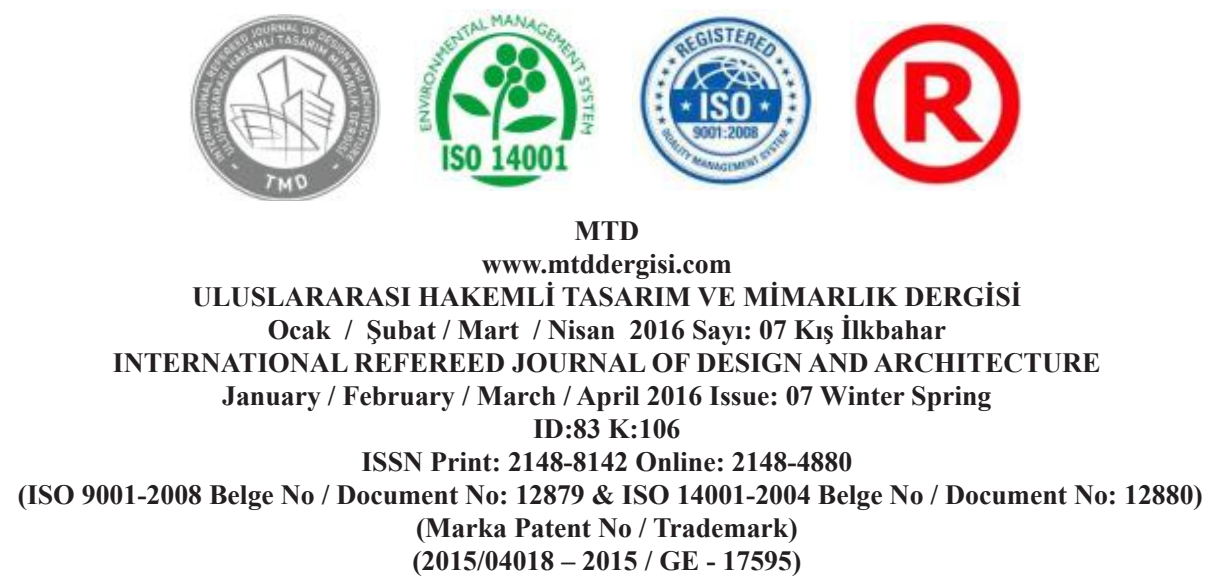

close to the floor, the most effective result was achieved

\section{EVALUATION}

\section{Scenario A: Analyzing the environment conditions of the pathology laboratory dur-}

ing a fire: Visibility distance is defined as the perception distance of the distances needed to reach the exits by individuals during a fire simulation. According to NFPA standards, the visibility distance must be 5 meters in small places, 10 meters in large places and up to 2 meters above the ground should be clear. In the light of these principles, when no precautions have been taken against smoke spread or dispersal, if the visibility distance and temperature values do not exceed the security limits, the location can be safely evacuated during the first 48 seconds following the start of the fire. At the end of 60 seconds, the smoke fell to below 2 meters causing the visibility distance to fall to 10-15 meters. At the end of 72 seconds, the laboratory was filled with smoke so that it no longer met the security values and the visibility distance in the corridor wings connecting the offices fell to less than 10 meters. At the end of 96 seconds, the whole laboratory section was under the effect of intense smoke intoxication. From this point on, there was a life-threatening situation in the laboratory. Reduction of visibility distance to below 5 meters makes it difficult for people to reach the exits and affects their psychology negatively, making them prefer to go back rather than forward as they are unable to predict the situation in the area that they cannot see.

It is assumed that exhaust fans start working immediately with the start of a fire. There is no obligation about smoke evacuation in the "'Fire Protection in Buildings Regulation 2009'. However, in provision 88-3, it is stated that in boiler rooms larger than 2000 $\mathrm{m} 2$, and parking areas etc., it is necessary to extract smoke with at least 10 air changes per hour. Although the places where analysis was conducted were smaller than $200 \mathrm{~m} 2$, the smoke extraction was conducted with 10 air changes. Despite evident smoke dispersal at the end of 300 seconds, the safety limit value (tenability) of the corridors could not be reduced below 10 meters visibility distance. Smoke evacuation made with 13 air changes per hour resulted in clear visibility distance up to 25 meters in every corridor and room. At the end of 300 seconds, the ceiling temperature of the laboratory and depot reached as high as $170^{\circ} \mathrm{C}$ and was seen to have exceeded $100^{\circ} \mathrm{C}$ in other office sections and corridors (Figure 1-2-3-4). It was seen that butanol, propanol and methanol which can easily ignite and swiftly burn, and formaldehyde gases, alcohols and ketones with a flash point under $37.7^{\circ} \mathrm{C}$ were stored as liquids (http://www.nbcdfw.com/).According to the 

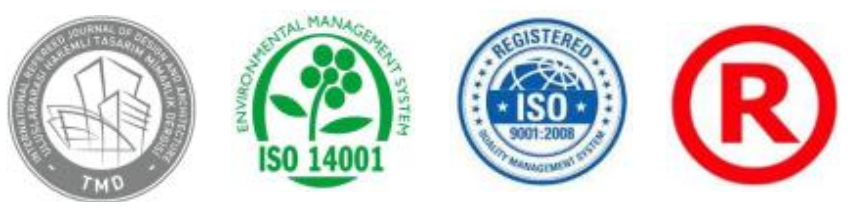

MTD

www.mtddergisi.com

ULUSLARARASI HAKEMLI TASARIM VE MIMARLIK DERGISİ

Ocak / Şubat / Mart / Nisan 2016 Sayı: 07 Kış İlkbahar

INTERNATIONAL REFEREED JOURNAL OF DESIGN AND ARCHITECTURE

January / February / March / April 2016 Issue: 07 Winter Spring ID:83 K:106

ISSN Print: 2148-8142 Online: 2148-4880

(ISO 9001-2008 Belge No / Document No: 12879 \& ISO 14001-2004 Belge No / Document No: 12880)

(Marka Patent No / Trademark)

$(2015 / 04018-2015$ / GE - 17595)

analyses, it was seen that when the temperature of the storage places of the liquids in question increased above $50^{\circ} \mathrm{C}$ after $48 \mathrm{sec}$ onds, after 72 seconds it had reached $80-90^{\circ} \mathrm{C}$ (Anonymous, 2008). That the environment temperature reaches these levels causes liq- uids and gases above the flash point to accelerate the fire and explode. In this aspect, that the laboratory is on the ground floor of the clinic block with 7 floors endangers the lives of all patients.
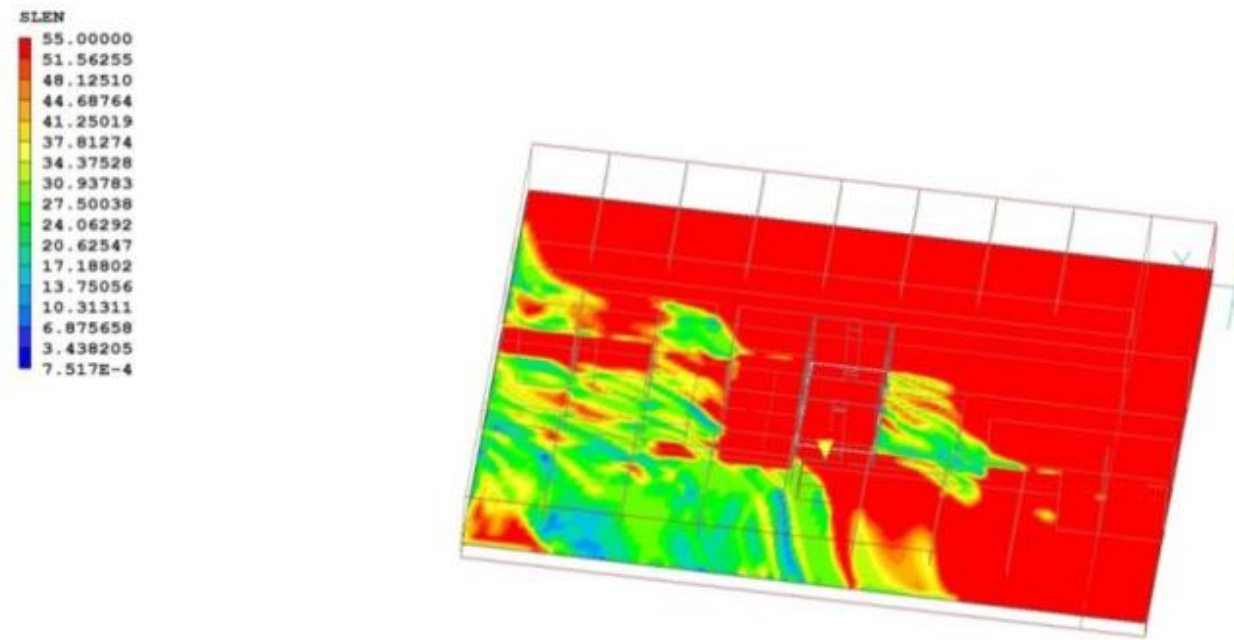

Figure 1. Visibility Distance Value After Starting the Extractor Fan (scenario A1)
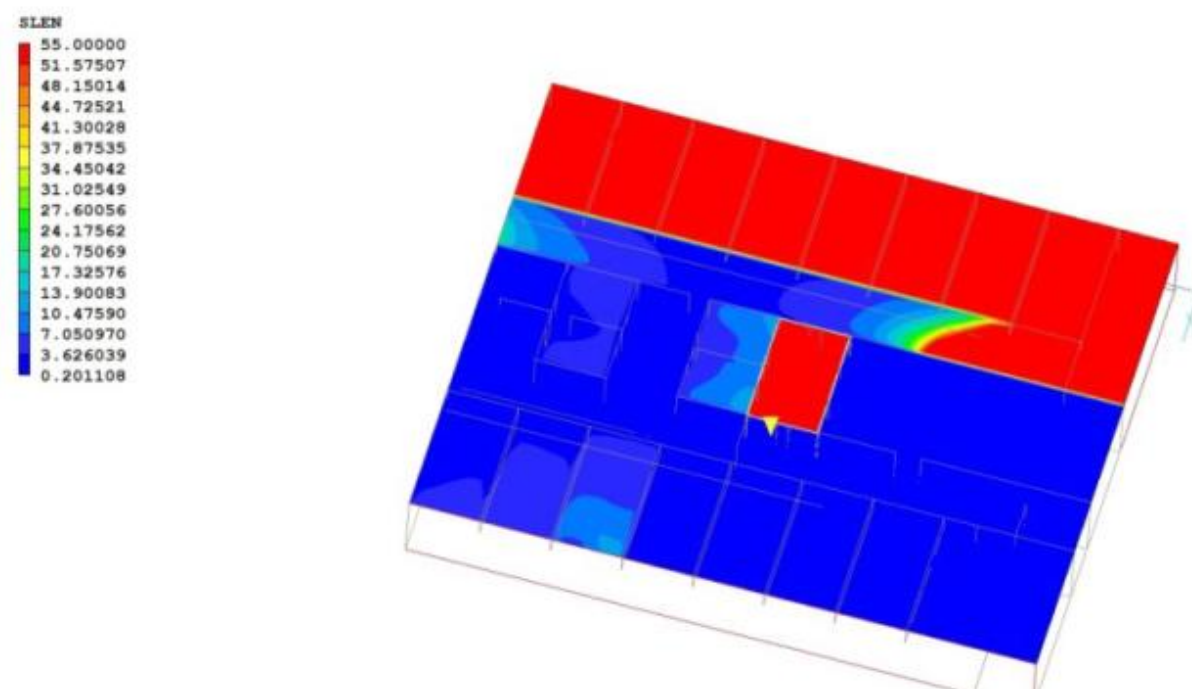

Figure 2. Visibility Distance of the Current Situation (Scenario A) 

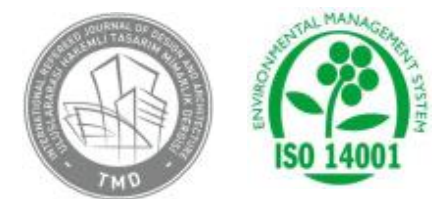

ISO 14001
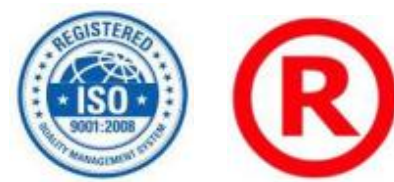

MTD

www.mtddergisi.com

ULUSLARARASI HAKEMLİ TASARIM VE MIMARLIK DERGİSI

Ocak / Şubat / Mart / Nisan 2016 Sayı: 07 Kış İlkbahar

INTERNATIONAL REFEREED JOURNAL OF DESIGN AND ARCHITECTURE

January / February / March / April 2016 Issue: 07 Winter Spring ID:83 K:106

ISSN Print: 2148-8142 Online: 2148-4880

(ISO 9001-2008 Belge No / Document No: 12879 \& ISO 14001-2004 Belge No / Document No: 12880)

(Marka Patent No / Trademark)

(2015/04018 - 2015 / GE - 17595)

Temperature, $" c$
288.3255
271.5843
254.8430
238.1018
221.3606
204.6194
187.8782
171.1369
154.3957
137.6545
120.9133
104.1721
87.43085
70.68964
53.94842
37.20720
20.46598

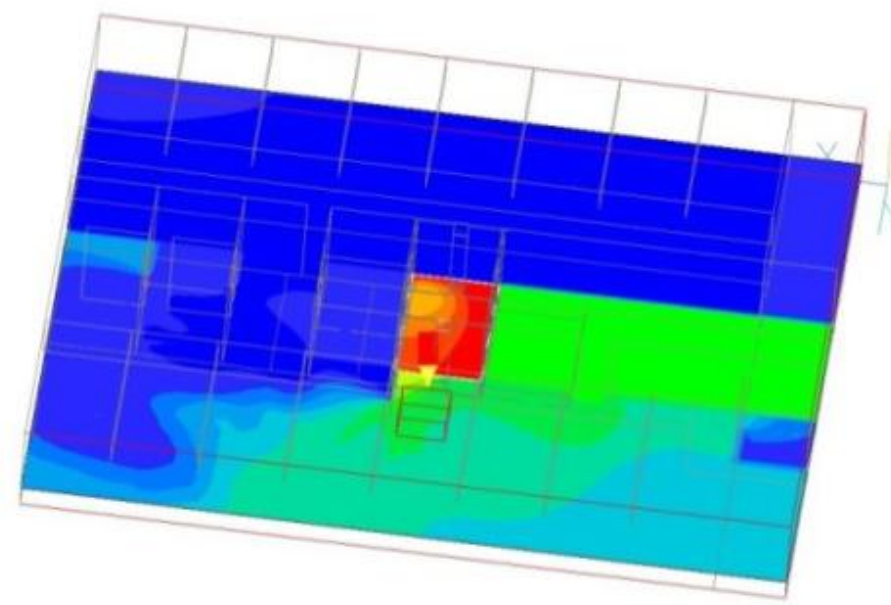

Figure 3. Temperature Values
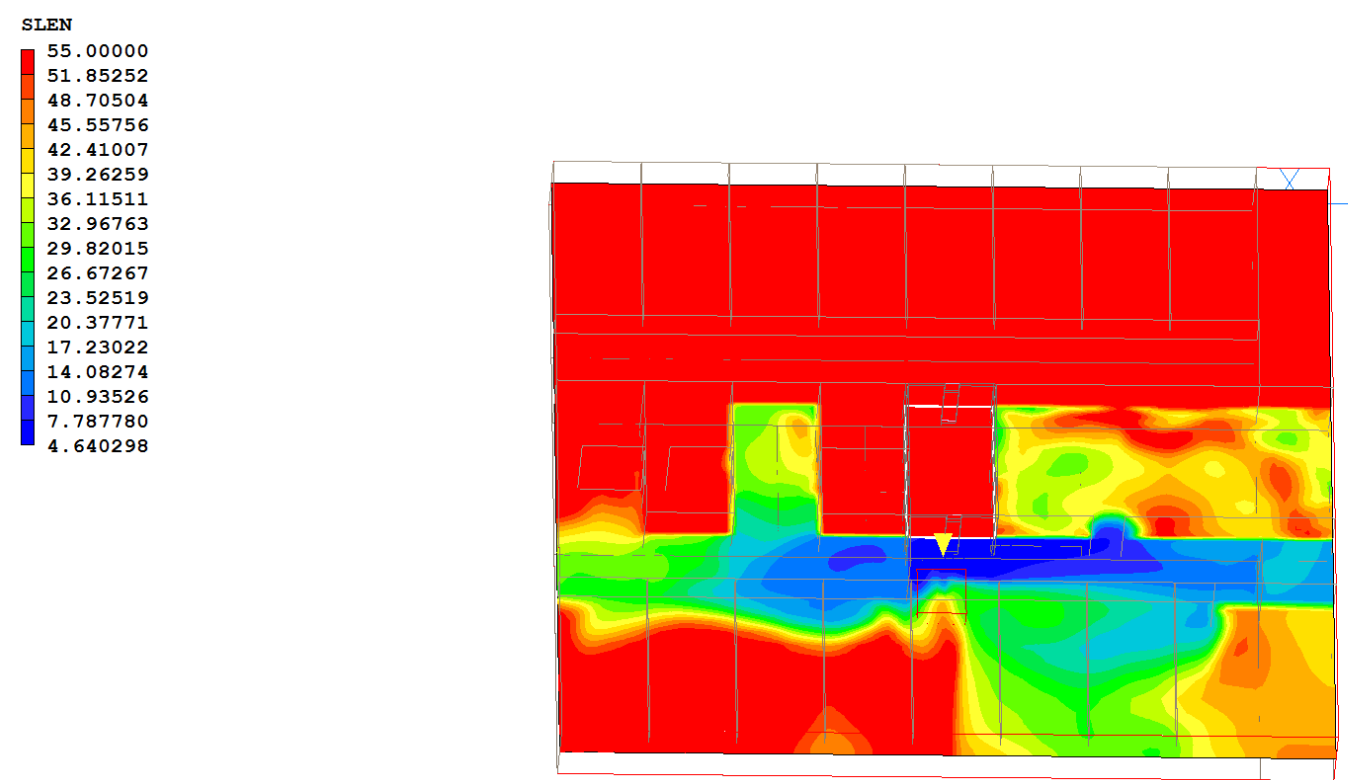

Figure 4. Visibility Distance Values of an Alcohol Fire With Extractor Fans (Scenario A2) 


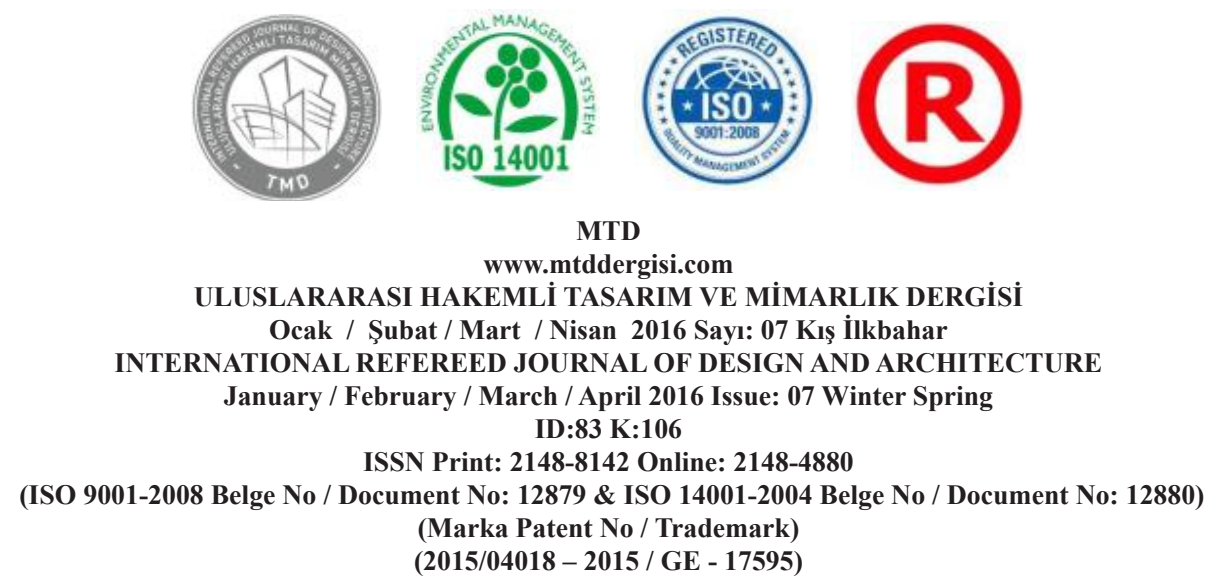

It has been shown that locating exhaust fans close to the ceiling causes smoke to diffuse and quickly fill the room rather than diluting the poisonous gasses. The required value of $5 \mathrm{~m}$ visibility distance in small spaces can be attained by extractor fans giving 17 air changes per hour or locating them near the ground. The temperature of the storage areas was seen to rise significantly 48 seconds after the fire started in the laboratory area. Flames spreading to these areas will accelerate the fire with flammable and explosive chemicals reaching flash point. There is a separate storage area in the department where samples embedded in paraffin blocks are kept. When paraffin is exposed to heat, it first becomes liquid, then steam or gas and burns. Therefore, there is a need for these storage areas to be designed as a separate compartment resistant to fire for at least 120 minutes with at least 6 air changes per hour.In the scenario of a fire starting due to the ignition of alcohol compounds that are kept in in the corridor in the same laboratory section, because the specific weight of alcohol is heavier than that of air, it came down to floor level making smoke evacuation difficult and in the same way, at the end of 150 seconds the smoke could not be brought under safe limit conditions. The visibility distance of $5 \mathrm{~m}$ for small areas could be reached when smoke evacuation was applied with 17 air changes per hour. However, the full significance of dispersal of the smoke from the environment with a single fan as in scenario A cannot be considered. This situation results from the different stoichiometric ratios defining the combustion status effect of the materials defined as fuel (Anonymous, 2011).

\section{Scenario B; Analysis of the environment conditions in the intensive care unit at the} time of fire: As taking intensive care unit patients out of the environment even for a short time can endanger their vital functions, it is aimed to maintain the $\mathrm{CO}$ level of the environment at a level which does not affect the patients. Existing environment conditions where there is no smoke evacuation system, state that at 60 seconds from the start of a fire, smoke covers the whole intensive care unit and reduces the visibility distance to less than 5 meters. At 150 seconds the temperature has been determined to reach $150^{\circ} \mathrm{C}$. When the temperature exceeds $120^{\circ} \mathrm{C}$, serious skin burns occur. When water vapor is less than $10 \%$ of the whole volume, respiratory tract burns and skin burns are observed (Anonymous, 2013). If the human body temperature reaches $44.8^{\circ} \mathrm{C}$, painful superficial burns occur (Shen, 2003). This shows that the environment conditions are well below the safety limit values. With the onset of fire, the activation of one air conditioning shaft connected to a smoke evacuation system opening on to the intensive care unit was seen to quickly 

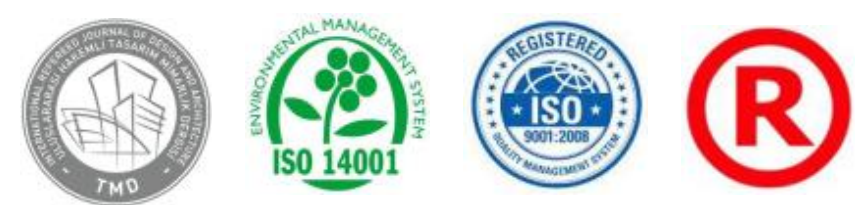

MTD

www.mtddergisi.com

ULUSLARARASI HAKEMLI TASARIM VE MIMARLIK DERGİSI

Ocak / Şubat / Mart / Nisan 2016 Sayı: 07 Kış İlkbahar

INTERNATIONAL REFEREED JOURNAL OF DESIGN AND ARCHITECTURE

January / February / March / April 2016 Issue: 07 Winter Spring ID:83 K:106

ISSN Print: 2148-8142 Online: 2148-4880

(ISO 9001-2008 Belge No / Document No: 12879 \& ISO 14001-2004 Belge No / Document No: 12880)

(Marka Patent No / Trademark)

$(2015 / 04018-2015$ / GE - 17595)

disperse smoke and at the end of 150 seconds the toxic effect of the smoke was below the limit value. As the intensive care unit is divided into two compartments and the rooms facing the patient treatment section are closed with doors which do not allow smoke to permeate, the smoke evacuation reaches the safety limit value faster. Thus, fewer patients are affected by the smoke (Figures 5-6). According to NFPA 101, in cases where intensive care is provided in a single intensive care unit on one floor, it should be divided into sub-compartments which are resistant to fire for at least 2 hours and are impermeable to smoke. If there is more than one intensive care unit on the same floor, each unit needs to be designed as a lateral shelter area for the other one. Taking into consideration that if the fire cannot be brought under control on the same floor and smoke spreads to these areas, each unit should have direct access out of the building. This is possible only when the units are on the ground floor or fire doors open on to ramps for patient evacuation.
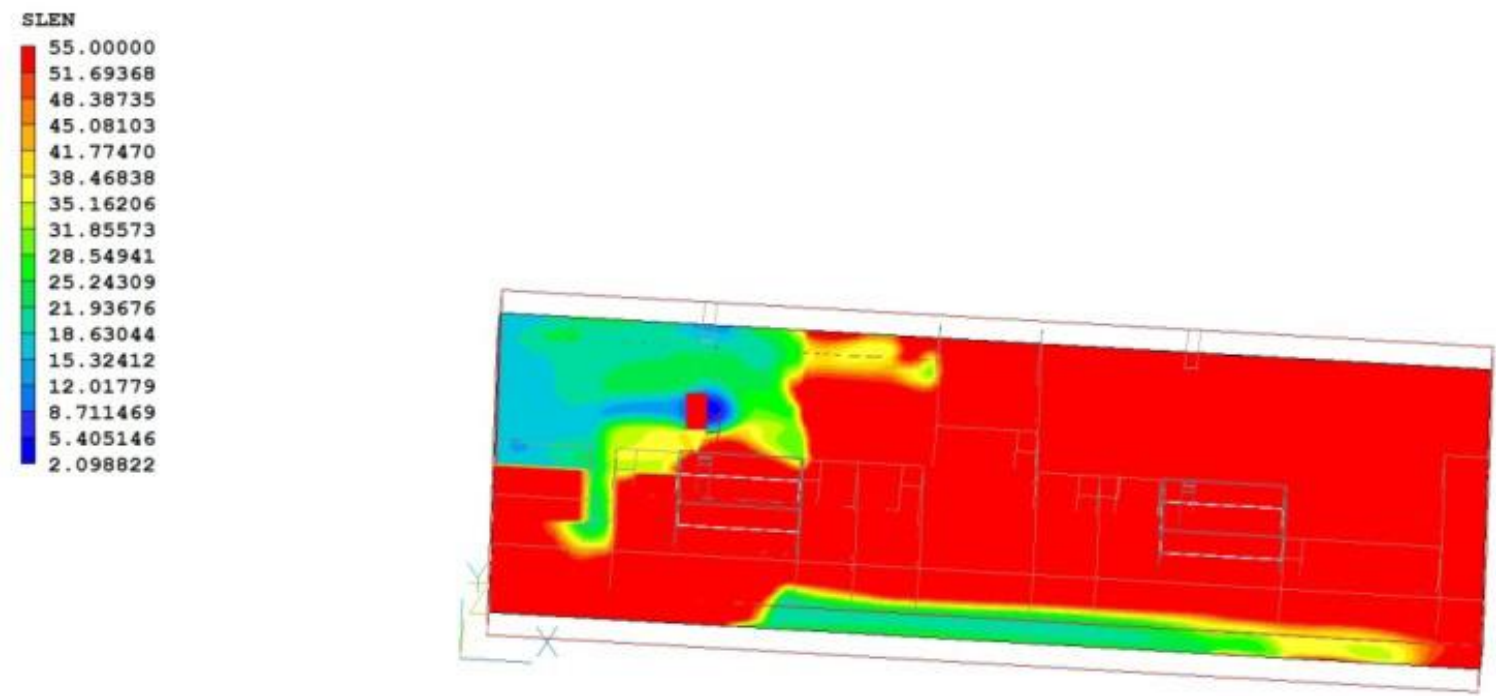

Figure 5. Visibility Values of $150 \mathrm{sc}$ 


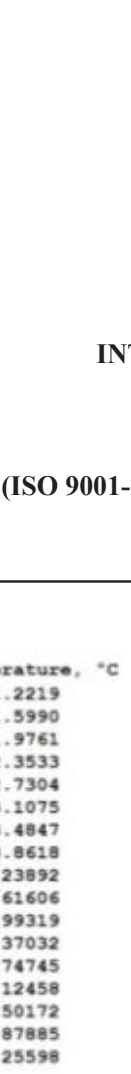
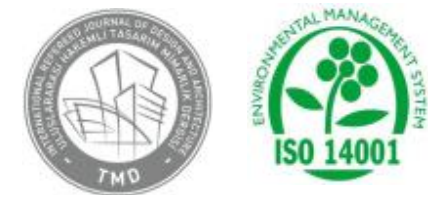

ISO 14001

MTD

Www.mtddergisi.com

ULUSLARARASI HAKEMLİ TASARIM VE MIMMARLIK DERGİSI

Ocak / Şubat / Mart / Nisan 2016 Sayı: 07 Kış İlkbahar

INTERNATIONAL REFEREED JOURNAL OF DESIGN AND ARCHITECTURE

January / February / March / April 2016 Issue: 07 Winter Spring ID:83 K:106

ISSN Print: 2148-8142 Online: 2148-4880

(Marka Patent No / Trademark)

(2015/04018 - 2015 / GE - 17595)
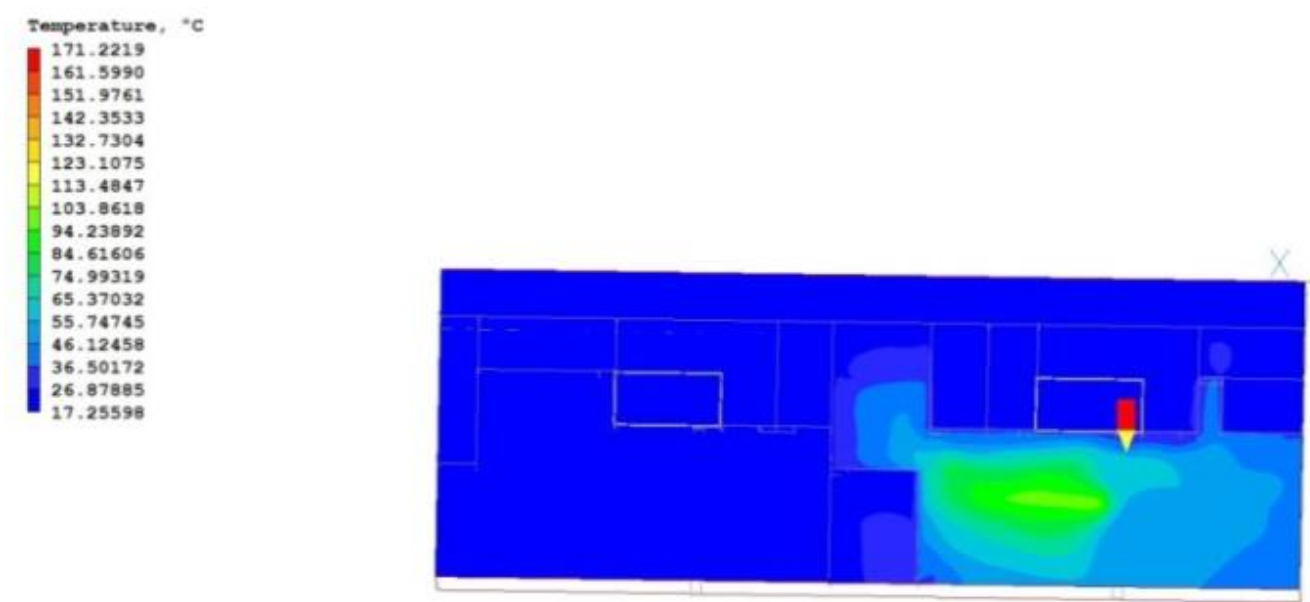

Figure 6. Tempeture Values of $150 \mathrm{sc}$

In the evaluation of the effects on human health according to the $\mathrm{CO}$ results: in a fire in the intensive care unit under normal conditions, $\mathrm{CO}$ expression at a value of 700 $1100 \mathrm{ppm}$ has been observed. This value produces symptoms such as headache, reddening, nausea, dizziness, weakness, irritability, unconsciousness, and leg and chest pain in patients with previous heart disease or vascular obstruction and fatal results (http://www. thehindu.com).

\section{CONCLUSION}

When there is no smoke evacuation system, at 60 seconds after fire breaks out, smoke has been seen to reach such a level that it prevents perception of escape routes and creates negative effects. In a report of a fire drill conduct- ed at a hospital it was determined that the last patient was evacuated from a clinic on the 7 th floor 40 minutes after the fire started, and evacuation of all the patients on the 3rd floor took 26 minutes (Anonymous c, 2009).In the case of a hospital fire which occurred in 2010 , all patients on the 7 th floor were evacuated in approximately 15 minutes. (Şimşek, 2013). After being exposed to smoke for 30 minutes, loss of movement up to a value of $1400 \mathrm{ppm}$ is experienced and continuation of the fire reaching a value of 2500 ppm will inevitably have fatal results (Poh, 2010). Therefore, there must definitely be a mechanical smoke evacuation system in patient areas and on all escape routes. One smoke extraction fan directed to the air conditioning shaft in both the pathology laboratory and the intensive 


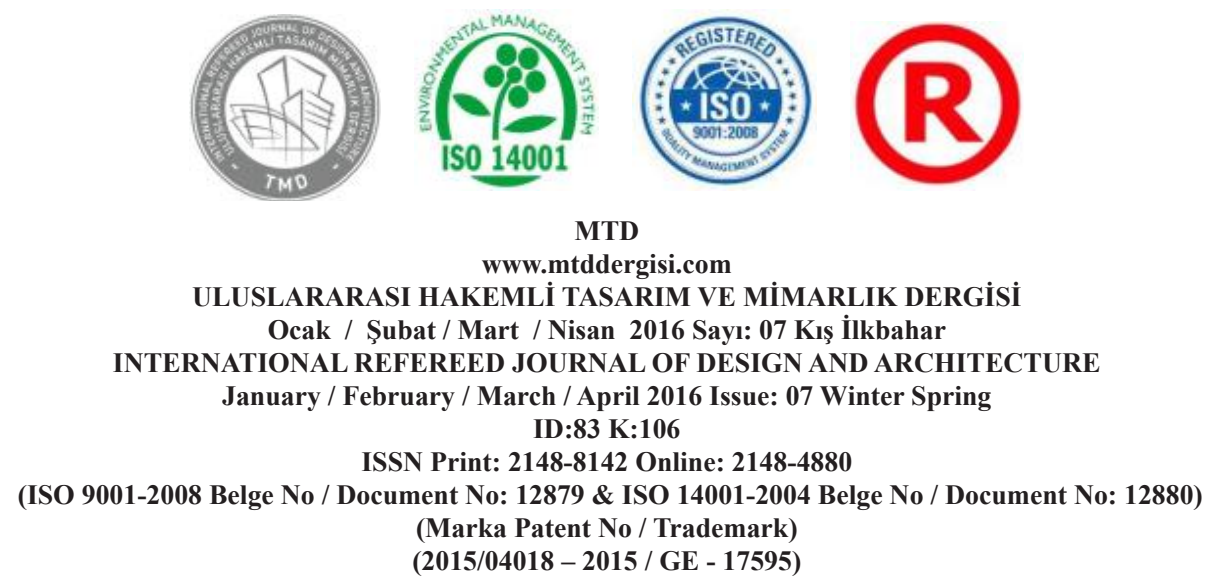

care unit worked sufficiently well to disperse smoke from the environment. However, this does not meet the condition of 10 air changes per hour defined by the regulations. In the event that alcohol evaporates and mixes with the environment air, fans providing at least 17 air changes are needed to provide adequate extraction.

Therefore, smoke extraction in laboratories needs to be more powerful compared to other areas and it needs to be applied from at least 2 points. In intensive care units, the conditions of least air change which are defined for the management of locations not using any combustible chemicals are seen to be valid. In the evacuation of hot smoke, the environment temperature decreased but the temperature could not be brought below the safe location limit values with the use of smoke evacuation systems. It was concluded that as smoke evacuation is necessary to increase visibility distance, it is appropriate to apply it in corridor sections that are used to reach exits but. it is not cost-effective and does not produce positive results in areas such as storage areas. To provide secure environment conditions, smoke evacuation alone is not enough. It is important to design systems which combine fire extinguishing systems and smoke detectors which activate when smoke reaches the ceiling after the outbreak of fire. When some compounds in the chemical store contact wa- ter, an explosion may occur. Therefore, as defined in NFPA 45 5.1.4., the unit needs to be equipped with a non-water gas extinguishing system to help bring the fire under control in a short time. Deficiencies determined in buildings and the necessary precautions to be taken are shown in Table 1. Therefore, to reduce the risks, pathology laboratories which carry an immediate fire risk should be designed to be distant from intensive care units and clinics. Thus locating pathology laboratories in a block independent from other units could be an option with connections of the bed units by covered tunnels. The doors opening to the tunnel connecting the two units should be selfopening and smoke-proof in order to prevent smoke spreading when evacuation is taking place. These are important precautions to be taken in order to eliminate the risks caused by smoke and fire (Figure 7).

Figure7. Patology-Hospital Connection

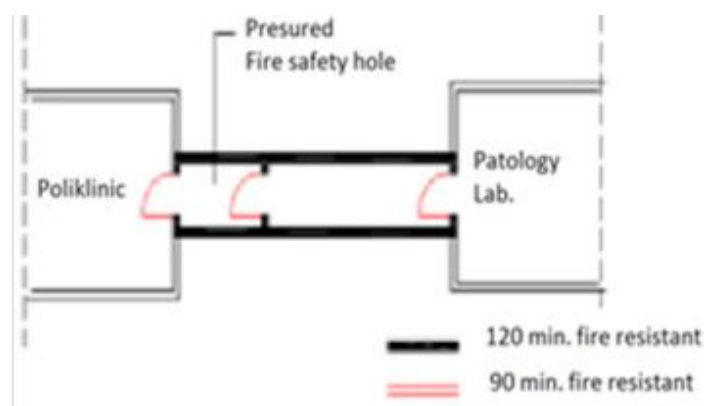

Necessary precautions to be taken within pathology laboratories have been defined. In the design of these areas, as in any place with laboratory the risk of explosion one side 


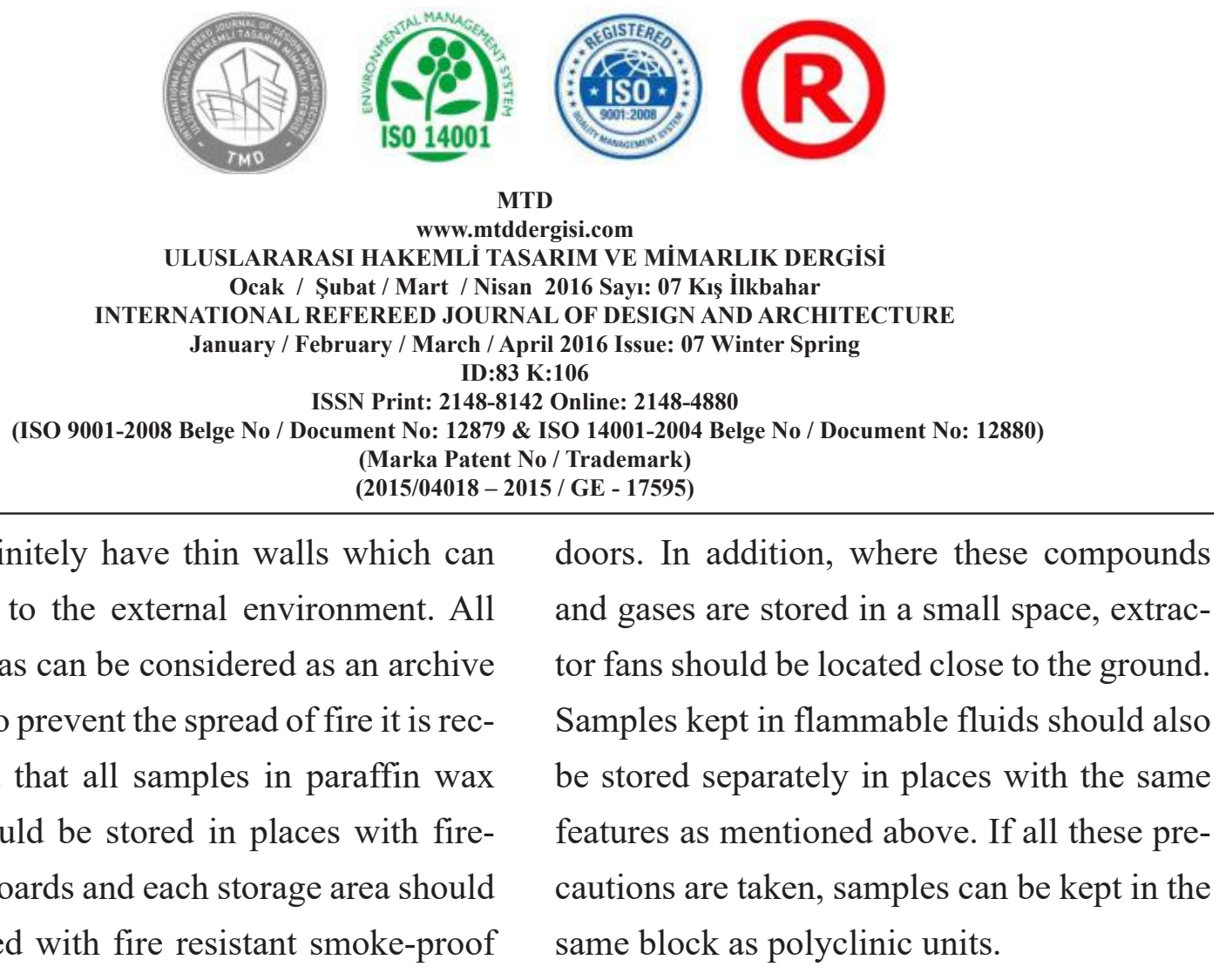

Table 1. Fire Safety Measurements Have to be Taken at Laboratory and Intensive Care Unit

\begin{tabular}{|c|c|}
\hline Fire safety regulation & Horizontal evacuation area \\
\hline $\begin{array}{l}\text { Intensive care unit } \\
\text { Pathology lab. }\end{array}$ & It must designed as an independent compartment area \\
\hline Fire safety regulation & Fire compartments design about fire spread \\
\hline Intensive care unit & It is designed as an independent compartment \\
\hline Pathology lab. & Offices, work places and storage areas are designed as a separate compartment \\
\hline Fire safety regulation & Smoke resistant in vertical\& horizontal shafts \\
\hline Intensive care unit & \multirow{2}{*}{$\begin{array}{l}\text { Smoke barriers were placed between each floor in all shafts. All shaft doors } \\
\text { materials are replaced by at least } 90 \text { minutes fire and smoke-resistant material. }\end{array}$} \\
\hline Pathology lab. & \\
\hline Fire safety regulation & Fire ladders provisions \\
\hline Intensive care unit & A ramp opened outdoor is designed suitable for stretcher evacuation \\
\hline Pathology lab. & Escape fire door designed opening direct to outside \\
\hline Fire safety Regulation & Electrical system \\
\hline $\begin{array}{l}\text { Intensive care unit } \\
\text { Pathology lab. }\end{array}$ & All electrical wiring replace with halogen free cables \\
\hline Fire safety regulation & Smoke control system in compartment \\
\hline Intensive care unit & \multirow{2}{*}{$\begin{array}{c}\text { Exhaust fans arranged at each compartment controlled by the automation } \\
\text { independent of the general vent. System and windows in the shaft closed, } 120 \\
\text { minutes fire resistance is provided. }\end{array}$} \\
\hline Pathology lab. & \\
\hline Fire safety regulation & Fire extinguishing systems provisions \\
\hline
\end{tabular}



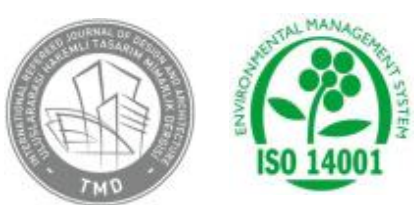

MTD

www.mtddergisi.com

ULUSLARARASI HAKEMLI TASARIM VE MIMARLIK DERGISİ

Ocak / Şubat / Mart / Nisan 2016 Sayı: 07 Kış İlkbahar

INTERNATIONAL REFEREED JOURNAL OF DESIGN AND ARCHITECTURE

January / February / March / April 2016 Issue: 07 Winter Spring ID:83 K:106

ISSN Print: 2148-8142 Online: 2148-4880

(ISO 9001-2008 Belge No / Document No: 12879 \& ISO 14001-2004 Belge No / Document No: 12880)

(Marka Patent No / Trademark)

$(2015 / 04018$ - 2015 / GE - 17595)

\begin{tabular}{|c|c|}
\hline Intensive care unit & \multirow{2}{*}{ The compartment equipped with Auto Fm 200 gas extinguishing systems. } \\
\hline Pathology lab. & \\
\hline Fire safety regulation & Explosive \& flammable gas. \\
\hline Pathology lab. & It should be taken out of building. \\
\hline Fire safety regulation & Does the Interior finishes provide fire resistance? \\
\hline Intensive care unit & \multirow{2}{*}{$\begin{array}{l}\text { Suspended ceiling linings and interior doors replaced with nonflammable } \\
\text { materials. }\end{array}$} \\
\hline Pathology lab. & \\
\hline Fire safety regulation & $\begin{array}{l}\text { Relationship of compartment with } \\
\text { dangerous places }\end{array}$ \\
\hline Intensive care unit & $\begin{array}{l}90 \text { min. fire resistant\& smoke-tight doors used in shafts. This compartment } \\
\text { designed vertically and horizontally far away distance, from places risk of } \\
\text { explosion. }\end{array}$ \\
\hline Pathology lab. & $\begin{array}{l}\text { Laboratory and storage should be taken out of building or should be moved to } \\
\text { inpatient floors or an independent building part. }\end{array}$ \\
\hline
\end{tabular}

NOTE: This study has been prepared under Uludağ Üniversitesi scientific research project (BAP)-(UAP(M) 2011/67) . Due to the contribution of our work, thanks to the Uludağ University Scientific Research Department.

\section{REFERENCES}

ANONYMOUS, (2008). Laboratory Safety Handbook. McMaster University Hamilton, Ontario

ANONYMOUS, A., (2009). CFPA-E Guideline, http://cfpa-e.eu/cfpa-e-guidelines/ guidelines-fireprotection - form/. Erişim Tarihi:10.12.2015

ANONYMOUS, B., (2009). Bursa Şevket Y1lmaz Devlet Hastanesi'nde meydana gelen yangın sebebiyle oluşan tahribatın önlenmesi amacıyla yangına karşı alınacak önlemlerin belirlenmesine yönelik rapor, Uludağ University, Bursa

ANONYMOUS, C., (2009). Uludağ Üniversitesi Tıp Fakültesi Hastanesi yangın tatbikatı gözlem ve sonuçları, Bursa

ANONYMOUS, (2011). Buji ile ateşlemeli motorlarda (bam) yanma ve emisyonla, Sakarya Üniversitesi ders notları.Sakarya, http://www.sahakk.sakarya.edu.tr.Erşim tarihi:08.012016

ANONYMOUS, (2013). The patient is on fire! A surgical fires primer, NewYork,http:// www.mdsr.ecri.org. 08.12.2015

HARRINGTON, J. M., SHANNON, H. S., (1977). Survey of safety and health care 


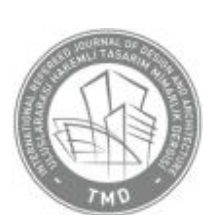
ISO 14001

MTD

Www.mtddergisi.com

ULUSLARARASI HAKEMLİ TASARIM VE MIMMARLIK DERGİSI

Ocak / Şubat / Mart / Nisan 2016 Sayı: 07 Kış İlkbahar

INTERNATIONAL REFEREED JOURNAL OF DESIGN AND ARCHITECTURE

January / February / March / April 2016 Issue: 07 Winter Spring ID:83 K:106

ISSN Print: 2148-8142 Online: 2148-4880

(ISO 9001-2008 Belge No / Document No: 12879 \& ISO 14001-2004 Belge No / Document No: 12880)

(Marka Patent No / Trademark)

$(2015 / 04018$ - 2015 / GE - 17595)

in British medical Laboratories, British Medical journal, 5;1(6061): 626-628

JEGATHESAN, C.S.C., LIM., (1998). Safe-

ty In Pathology Laboratories, Malaysian J Pathol. Institute for Medica Research, Kuala Lumpur, Malaysia, 10:1-5

POH, $\boldsymbol{W}$. , (2010). Tenability inbuilding fires:

Limits and design criteria, Fire. Australia, https://www.engineersaustralia. org.12.02.2016
PROULX, G., (2002). Evacuation planning for occupants with disability, Internal report no.843, NRC-CNRC, Ottowa

SHEN, T, S., (2003). Building planning evaluations for emergency evacuation, Doktora Tezi, Worcester Polytechnic Institute, U.S.A

SHIELDS, T.J., SILCOCK G.W.H., (1987). Buildings and fire. Longman Scientific \&Technical, http://www.nbcdfw.com. 12.02.2016 